\title{
Note
}

\section{Paleoenvironmental Analysis of a Core Sediment from the Toyooka Basin, Hyogo Prefecture, Japan. -A Study Using Diatom Analysis Combined with Selective Chemical Extraction-}

\author{
Hiroshi Sato
}

\begin{abstract}
A study using diatom analysis combined with selective chemical extraction was conducted to interpret paleoenvironmental changes in the core sediment obtained near the Maruyama-gawa River in Toyooka Basin, Hyogo Prefecture.

A sediment sample was leached subsequently with $1 \mathrm{~N} \mathrm{HCl}$ and $30 \% \mathrm{H}_{2} \mathrm{O}_{2}$. The remaining silicate fraction was used for the diatom analysis. In the present study, pyrite-sulfur $\left(\mathrm{FeS}_{2}-\mathrm{S}\right)$ content determined in the $30 \% \mathrm{H}_{2} \mathrm{O}_{2}$ soluble fraction was employed to distinguish marine from freshwater depositional condition and a new diatom-based index of paleosalinity (DIPs) was proposed for the estimation of salinity changes in sedimentary environments. Because of the complementarity between pyrite and diatom analysis in muddy sediments, this method provided continuous and detailed information on the paleoenvironmental changes.

Based on the variation of the DIPs and pyrite content, six phases were distinguished in the present core sample, reflecting salinity changes in sedimentary environments probably caused by the marine transgressions and regressions. The phase variations were consistent with Holocene sea-level changes presumed by variations in $\delta^{13} \mathrm{C}$ values and the $\mathrm{C} / \mathrm{N}$ ratios in the same core sample (NaKaI et al., 1989).
\end{abstract}

Key words: diatom analysis, selective chemical extraction, pyrite-sulfur, diatom-based index of paleosalinity (DIPs)

\section{Introduction}

Diatom analysis of sediments has been used to clarify the changes in sedimentary environments caused by the marine transgressions and regressions in coastal areas (SATO and Kumano, $1985,1986)$. Information on the variation of diatom assemblages, however, is not always obtained because the sediment sample has insufficient diatoms to accomplish a reliable analysis. In order to obtain continuous paleoenvironmental information, another analytical technique should be applied along with the diatom analysis.

The sediment matrix itself also has a potential for providing detailed information on the changes in sedimentary environment. Variation of a particular chemical component in sediments was employed to elucidate the sedimentary environment (Koмs et al., 1983, 1988, 1989). These studies indicated that sulfur content can be used to determine whether the sediment was deposited under marine or freshwater conditions. Sulfur in sediments can be fractionated into sulfate-sulfur soluble in water, sulfate-sulfur soluble in $\mathrm{HCl}$, sulfides,elemen- 
tal sulfur, disulfide-sulfur (mainly of pyrite) and organic sulfur (Koma et al., 1983).

Pyrite $\left(\mathrm{FeS}_{2}\right)$ is a major end product of sulfate reduction and sulfide precipitation in sediments. Pyrite formation depends on a variety of factors, including the abundance of dissolved sulfate, reactive iron minerals and organic matter that sulfate-reducing bacteria can respire (BERNER, 1984). Much more pyrite is usually found in brackish and marine muddy sediments in comparison with freshwater conditions (Postoma, 1982). In consequence, pyrite content in sediments was used to distinguish marine from freshwater depositional condition (e.g. NAKAI et al., 1982). The pyrite analysis method is based on the difference in sulfate contents in fresh and seawater; seawater contains, on average, $28 \mathrm{mmol} \cdot 1^{-1}$ of $\mathrm{SO}_{4}{ }^{2-}$, which is more than a hundred times more than in freshwater (BERNer and Raiswell, 1984). Pyrite analysis is a useful tool in elucidating the sedimentary environment, particularly when the sediment sample contains few diatom frustules. However, possible pyrite oxidation may have to be taken into consideration, when utilizing the pyrite content as a clue to elucidate sedimentary environments (Chigira, 1988, Sato, 1989).

Sulfate-sulfur and pyrite-sulfur can be separately determined by selective chemical extraction of a sediment sample with $\mathrm{HCl}$ and subsequently with $\mathrm{H}_{2} \mathrm{O}_{2}$ (Kitano et al., 1980). Diatom analysis, if combined with selective chemical extraction, will provide more precise information for paleoenvironmental interpretations.

In this paper, a method using the diatom analysis combined with selective chemical extraction was presented for detailed paleoenvironmental interpretation. The method was applied to a core sediment obtained in an area near the Maruyama-gawa River in the Toyooka Basin, Hyogo Prefecture. Extractable sodium and potassium were also measured to understand their behaviors in depositional and diagenetic conditions.

\section{Materials and methods}

\section{2-1. Samples}

The core sample used in the present study was obtained from a hole bored near the Mar. uyama-gawa River in the Toyooka Basin in February 1988 (Fig. 1). The core sample (Holocene deposit), which has a total length of ca. $42 \mathrm{~m}$, is composed mainly of silt, peaty silt and sandy sediments. Shell fossils were found in the horizons between $-10 \mathrm{~m}$ and $-28 \mathrm{~m}$. By the radiocarbon method, the shell fossils at horizons of about $-16 \mathrm{~m}$ and $-17 \mathrm{~m}$ were dated as $5,150 \pm 320$ yr. B. P. and $6,900 \pm 580$ yr. B. P., respectively (NAKAI et al., 1989). The Holocene transgression was shown to have

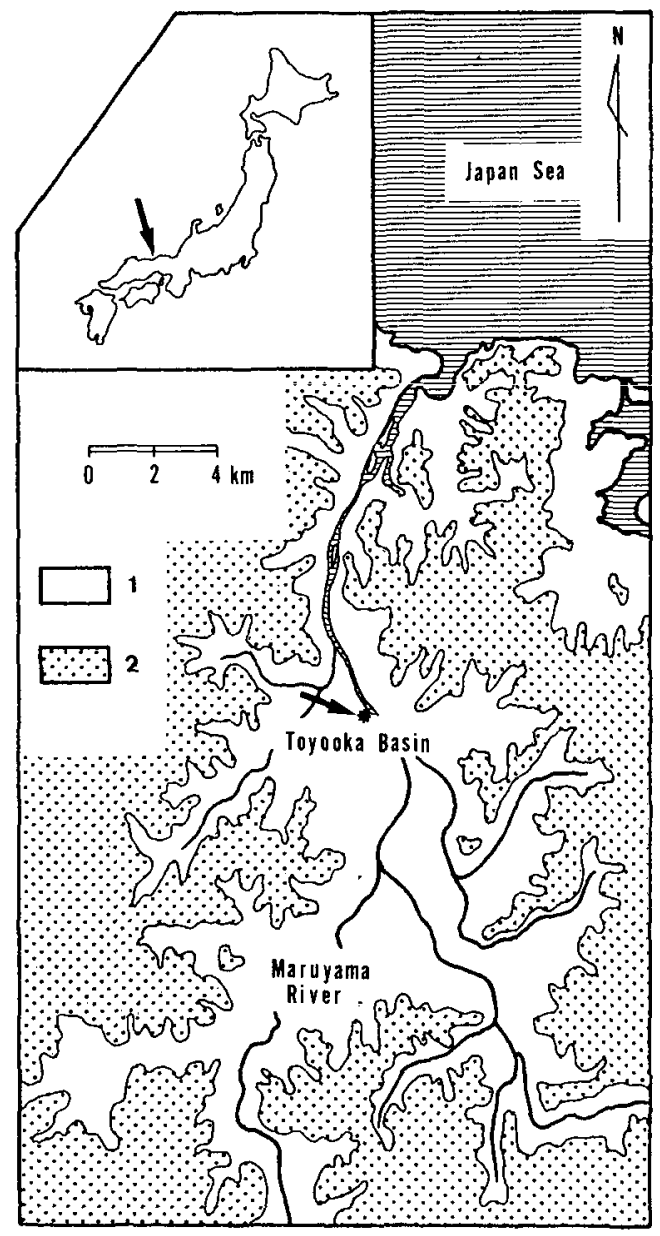

Fig. 1. Map showing the location of boring site (1; lowland, 2; upland). 
culminated in these ages by analyses of the stable carbon isotopic composition $\left({ }^{13} \mathrm{C} /{ }^{12} \mathrm{C}\right)$ and the $\mathrm{C} / \mathrm{N}$ ratio of sedimentary organic matter (NAKAI et al., 1989). For the present study, twenty-seven samples were taken at approximately every $1.0 \mathrm{~m}$ interval from the horizons between $-2 \mathrm{~m}$ and $-30 \mathrm{~m}$ (Fig. 3).

\section{2-2. Procedure}

The selective chemical leaching technique developed by Kitano et al. (1980) was applied to the present analysis. The flow chart of chemical leaching procedure is shown in Figure 2. Sodium, potassium, iron and sulfur contents were determined in the $1 \mathrm{~N} \mathrm{HCl}$ soluble and $30 \%$ $\mathrm{H}_{2} \mathrm{O}_{2}$ soluble fractions for 27 sediment samples. Residual silicate fractions were used for the diatom analysis. Sodium and potassium in each fraction were determined by atomic absorption spectrophotometry. Iron was determined colorimetrically by the phenanth- roline method and sulfate was determined by turbidimetric method (APHA et al., 1985).

\section{2-2-1. 1N HCl soluble fraction}

One gram of dried sediment was treated with $10 \mathrm{ml}$ of $1 \mathrm{~N} \mathrm{HCl}$ in a $200 \mathrm{ml}$ conical beaker for 45 minutes on a hot plate set at $80-90^{\circ} \mathrm{C}$. After adding $30 \mathrm{ml}$ of distilled water, the whole sample solution was centrifuged ( $3,000 \mathrm{rpm}, 15 \mathrm{~min}$ ) and the supernatant was saved. The centrifugation was repeated twice and the supernatant was made up to $100 \mathrm{ml}$.

\section{2-2-2. $30 \% \mathrm{H}_{2} \mathrm{O}_{2}$ soluble fraction}

The residue remaining after the first $1 \mathrm{~N} \mathrm{HCl}$ treatment was then digested with $10 \mathrm{ml}$ of $30 \%$ $\mathrm{H}_{2} \mathrm{O}_{2}$ and $2 \mathrm{ml}$ of $3 \mathrm{~N} \mathrm{HCl}$ for 2-5 minutes at $80^{-}$ $90^{\circ} \mathrm{C}$ and then left to stand overnight at room temperature. Pyrite in the sediments can be completely dissolved by this treatment (KITANO et al., 1980). The sample solution was centrifuged $(3,000 \mathrm{rpm}, 15 \mathrm{~min})$ and the super-

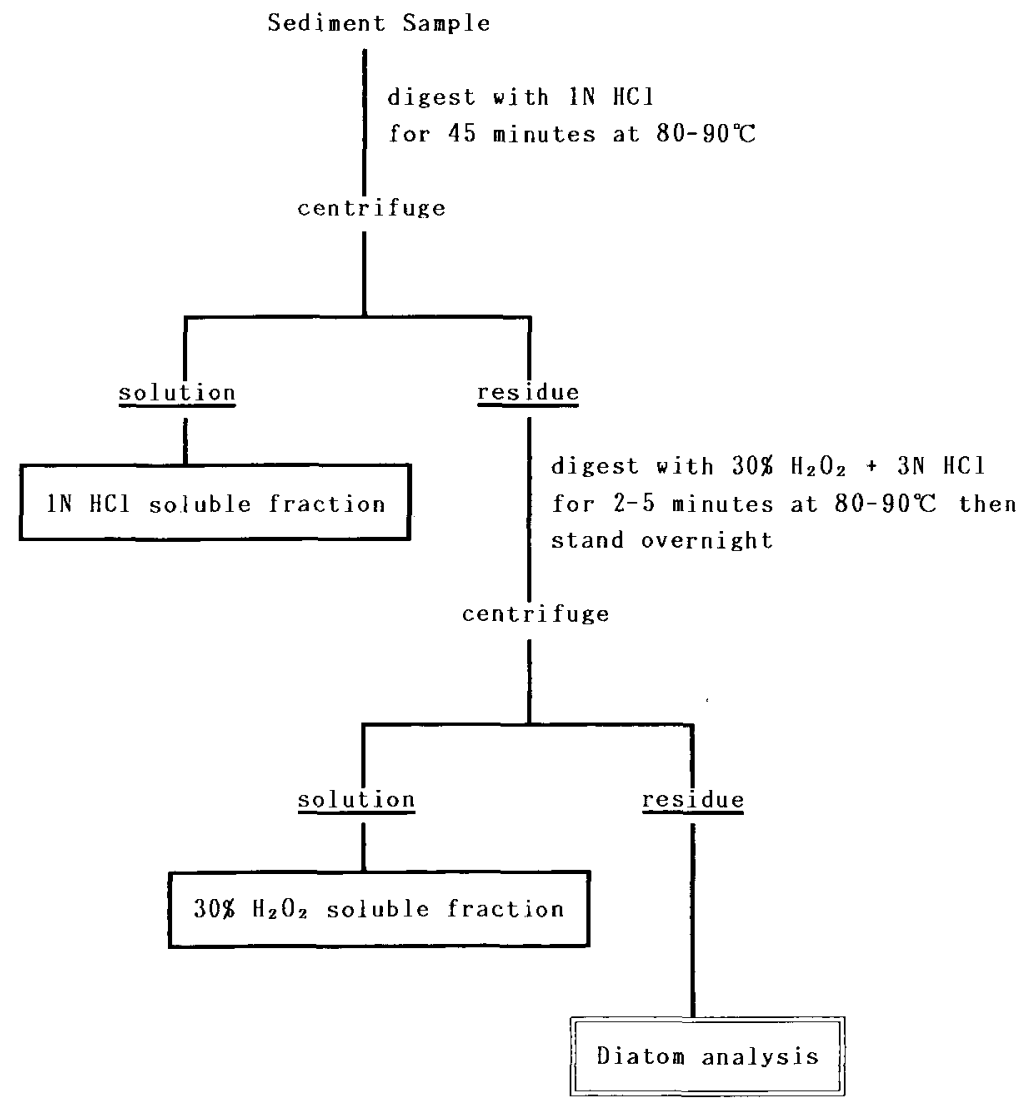

Fig. 2. Flow diagram of the selective chemical leaching. 
natant was saved. The solution was made up to $100 \mathrm{ml}$.

\section{2-2-3. Diatom analysis}

After the $\mathrm{HCl}$ and successive $\mathrm{H}_{2} \mathrm{O}_{2}$ treatments, the residue consisting almost entirely of clay and other silicate minerals was used for the diatom analysis. The sample was dispersed in $200 \mathrm{ml}$ of $1 \%$ sodium pyrophosphate solution. The fine mineralogenic material was removed by decantation. The diatom fraction was separated from the remainder by vibration and subsequent decantation of the suspension containing diatom frustules, which take longer to. settle than the coarse materials. The diatom fraction was made up to a definite volume and $0.5 \mathrm{ml}$ of the suspension was dropped with a pipette onto a cover slip. The sample was dried on a hot plate. The preparations were mounted in Mountmedia (Wako Chemicals, Japan). The above procedure and the subsequent microtransect counting method (APHA et al., 1985) made it possible to estimate the concentration of diatom frustules per milligram of dry sediment.

The proportional counting was continued until more than 50 frustules of the most common taxon was found. Following the halobion system of Lowe (1974), diatoms were classified into six groups to reconstruct paleosalinity based on the diatom assemblages; halophobous (F1), indifferent (F2), halophilous (FB5), $\beta^{-}$ mesohalobous (BM10), $\alpha$-mesohalobous (M20) and euhalobous (M30) (Table 1).

Classification and identification of diatoms were principally according to Cleve-EuLER
(1951-1955), Hustedt (1930-1966), Patrick and Rejmer $(1966,1975)$, van der WerfF and Huls (1957-1974) and JонN (1983).

In this paper, a new diatom-based index of paleosalinity (DIPs) that is similar in form to the salinity index S proposed by DenYs (1984) was calculated for the estimation of salinity changes in sedimentary environments. The form of DIPs is as follows;

$$
\begin{aligned}
\mathrm{DIPS} & =P_{\mathrm{F} 1}^{-}+2 P_{\mathrm{F} 2}+5 P_{\mathrm{FB} 5} \\
& +10 P_{\mathrm{BM} 10}+20 P_{\mathrm{M} 20}+30 P_{\mathrm{M} 30}
\end{aligned}
$$

where, for example, $P_{\mathrm{m} 30}=$ the relative frequency of the group of euhalobous taxa (M30). According to the salinity range of six groups, each group was weighted with arbitrarily chosen coefficients. The smallest coefficient of 1 was given to the $P_{\mathrm{F} 1}$ because the halophobous diatoms do not tolerate small amounts of salt. A coefficient of 2 was assigned to the indifferent diatoms tolerating small amounts of salt, 5 to the halophilous ones stimulated by small amounts of salt, 10 to the $\beta$-mesohalobous ones occurring in salt concentrations of 500 to 10,000 (mg ${ }^{-1}{ }^{-1}$ ), 20 to $\alpha$-mesohalobous ones occurring in salt concentrations of 10,000 to 30,000 (mg • $1^{-1}$ ), and 30 to the euhalobous ones occurring in salt concentrations of 30,000 to $40,000\left(\mathrm{mg} \cdot \mathrm{l}^{-1}\right)$.

The DIPs value ranges from a minimum of 1.0 to a maximum of 30.0 . For example, if the diatom assemblage is composed entirely of freshwater diatoms, the DIPs value will range from 1.0 to 2.0, since the DIPs is given by $P_{\mathrm{F} 1}+$ $P_{\mathrm{F} 2}=1$ and $P_{\mathrm{FB} 5}=P_{\mathrm{BM} 10}=P_{\mathrm{M} 20}=P_{\mathrm{M} 30}=0$. Similarly, if the assemblage is composed entirely of

Table 1. Significant taxa of diatoms classified into six groups of the halobion system.

Euhalobous: Thalassiosira eccentrica

\section{Mesohalobous}

$\alpha$-range: Actinoptychus undulatus

Palaria sulcata

Cyclotella striata, C. stylorum

Grammatophora spp.

Diploneis smithii, D. suborbicularis

Nitzschia granulata, N. lanceolata, N. punctata

$\beta$-range: Cyclotella striata var. baltica

Diploneis pseudovalis
Oligohalobous

halophilous: Achnanthes crenulata

Navicula hungarica

Rhopalodia gibberula

indifferent: Achnanthes japonica, A. lanceolata

Cocconeis placentula

Cymbella spp.

Gomphonema spp.

Navicula radiosa, $N$, viridula

halophobous: Ceratoneis arcus

Eunotia spp. 
brackish diatoms $\left(P_{\mathrm{FB} 5}+P_{\mathrm{BM} 10}=1\right)$ of marine diatoms $\left(P_{\mathrm{M} 20}+P_{\mathrm{M} 30}=1\right)$, the DIPs value will range either from 5.0 to 10.0 or from 20.0 to 30.0 , respectively. Thus a low DIPs value indicates a predominance of freshwater influence and the increasing value will indicate the gradual increase of marine influence in sedimentary environments.

\section{Results}

\section{3-1. Sodium and potassium}

The amounts of sodium and potassium in the $30 \% \quad \mathrm{H}_{2} \mathrm{O}_{2}$ soluble fraction were negligibly small relative to those in $1 \mathrm{~N} \mathrm{HCl}$ soluble fraction (Table. 2). The sodium and potassium leached into $1 \mathrm{~N} \mathrm{HCl}$ soluble fraction are derived mainly from carbonate and from ionexchangeable sites on clay minerals (KITANo et al., 1980). Variation in sodium content tended to increase at the upper part of the profile. The largest amount was obtained in the sample No. $22(-8 \mathrm{~m})$, whereas potassium content profile showed larger amounts in the samples No. 11-14 (-16 m--19m) (Table 2, Fig. 3).

\section{3-2. Sulfur and iron}

The sulfur and iron contents of the chemically-separated fractions of sediments are shown in Table 2. The $\mathrm{S} / \mathrm{Fe}$ ratio of the $30 \%$ $\mathrm{H}_{2} \mathrm{O}_{2}$ soluble fraction ranged from 0.92 to 1.20 , the average of which was 1.08 except for samples No. 1, 22, 26, and 27 (Table 2). The sulfur and iron contents in the $30 \% \mathrm{H}_{2} \mathrm{O}_{2}$ soluble fraction approximately agreed with the stoichiometrical S/Fe ratio of pyrite (1.15), and are therefore assumed to be derived mainly from pyrite.

Table 2. Sodium, potassium, sulfur and iron contents $\left(\mathrm{mg} \cdot \mathrm{g}^{-1}\right)$ of chemically-separated fractions, the $\mathrm{S} / \mathrm{Fe}$ ratio of the $30 \% \mathrm{H}_{2} \mathrm{O}_{2}$ soluble fraction, and DIPs value.

\begin{tabular}{|c|c|c|c|c|c|c|c|c|c|c|c|c|}
\hline \multirow[b]{2}{*}{ Sample No. } & \multicolumn{2}{|c|}{$\mathrm{Na}$} & \multicolumn{2}{|c|}{$\mathrm{K}$} & \multicolumn{3}{|c|}{$\mathrm{S}$} & \multicolumn{3}{|c|}{$\mathrm{Fe}$} & \multirow{2}{*}{$\begin{array}{c}\mathrm{S} / \mathrm{Fe} \\
\text { in } \mathrm{H}_{2} \mathrm{O}_{2}\end{array}$} & \multirow[t]{2}{*}{ DIPS } \\
\hline & $\mathrm{HCl}$ & $\mathrm{H}_{2} \mathrm{O}_{2}$ & $\mathrm{HCl}$ & $\mathrm{H}_{2} \mathrm{O}_{2}$ & $\mathrm{HCl}$ & $\mathrm{H}_{2} \mathrm{O}_{2}$ & $\mathrm{HCl}+\mathrm{H}_{2} \mathrm{O}_{2}$ & $\mathrm{HCl}$ & $\mathrm{H}_{2} \mathrm{O}_{2} \mathrm{I}$ & $\mathrm{Cl}+\mathrm{H}_{2} \mathrm{O}_{2}$ & & \\
\hline 1 & 0.96 & 0.06 & 0.86 & 0.08 & 2.1 & 0.0 & 2.1 & 24.4 & 1.4 & 25.7 & - & 3.5 \\
\hline 2 & 0.81 & 0.05 & 0.70 & 0.05 & 5.9 & 15. & 21.0 & 24.8 & 13.6 & 38.4 & 1.12 & 13.6 \\
\hline 3 & 1.13 & 0.06 & 0.90 & 0.04 & 6.0 & 7.5 & 14.0 & 27.0 & 7.0 & 34.0 & 1.07 & 6.0 \\
\hline 4 & 1.61 & 0.06 & 1.21 & 0.05 & 6.4 & 4.5 & 11.0 & 26.5 & 4.4 & 30.9 & 1.02 & 5.0 \\
\hline 5 & 1.60 & 0.07 & 1.30 & 0.05 & 5.6 & 9.6 & 15.0 & 23.1 & 8.4 & 31.5 & 1.14 & 12.3 \\
\hline 6 & 1.52 & 0.05 & 1.18 & 0.05 & 5.2 & 6.9 & 12.0 & 24.7 & 6.0 & 30.7 & 1.15 & 10.8 \\
\hline 7 & 1.46 & 0.05 & 1.06 & 0.05 & 4.8 & 6.3 & 11.0 & 25.2 & 6.1 & 31.3 & 1.03 & 15.9 \\
\hline 8 & 1.63 & 0.05 & 1.20 & 0.06 & 6.9 & 7.3 & 14.0 & 24.1 & 6.7 & 30.8 & 1.09 & 14.8 \\
\hline 9 & 2.07 & 0.06 & 1.47 & 0.07 & 8.3 & 6.4 & 15.0 & 30.4 & 5.7 & 36.1 & 1.12 & 14.2 \\
\hline 10 & 2.10 & 0.06 & 1.54 & 0.08 & 3.7 & 9.9 & 14.0 & 24.5 & 8.3 & 32.8 & 1.19 & - \\
\hline 11 & 2.37 & 0.06 & 1.62 & 0.08 & 2.7 & 6.2 & 8.9 & 29.8 & 5.9 & 35.7 & 1.05 & - \\
\hline 12 & 2.40 & 0.06 & 1.60 & 0.08 & 8.7 & 5.3 & 14.0 & 26.9 & 4.8 & 31.7 & 1.10 & 15.9 \\
\hline 13 & 2.50 & 0.07 & 1.60 & 0.07 & 1.4 & 7.7 & 9.1 & 26.8 & 7.2 & 34.0 & 1.07 & 15.7 \\
\hline 14 & 2.50 & 0.07 & 1.60 & 0.08 & 2.5 & 8.7 & 11.0 & 23.5 & 7.7 & 31.2 & 1.13 & 15.9 \\
\hline 15 & 2.40 & 0.07 & 1.41 & 0.07 & 1.7 & 3.0 & 4.7 & 22.0 & 3.1 & 25.1 & 0.96 & - \\
\hline 16 & 2.43 & 0.06 & 1.40 & 0.07 & 3.2 & 2.6 & 5.8 & 22.0 & 2.8 & 24.8 & 0.93 & - \\
\hline 17 & 2.59 & 0.07 & 1.45 & 0.09 & 3.7 & 4.5 & 8.2 & 30.3 & 4.2 & 34.5 & 1.07 & - \\
\hline 18 & 2.86 & 0.07 & 1.42 & 0.07 & 4.1 & 3.5 & 7.6 & 22.2 & 3.8 & 26.0 & 0.92 & 12.4 \\
\hline 19 & 2.78 & 0.07 & 1.20 & 0.05 & 1.1 & 5.8 & 6.9 & 42.5 & 5.7 & 48.2 & 1.02 & 10.8 \\
\hline 20 & 2.58 & 0.07 & 0.89 & 0.06 & 5.7 & 6.0 & 12.0 & 19.2 & 5.0 & 24.2 & 1.20 & 8.8 \\
\hline 21 & 3.04 & 0.07 & 1.23 & 0.07 & 4.3 & 4.6 & 8.9 & 24.0 & 4.3 & 28.3 & 1.07 & 7.7 \\
\hline 22 & 3.92 & 0.10 & 0.88 & 0.06 & 11. & 0.0 & 11.0 & 19.6 & 1.9 & 21.5 & - & 3.1 \\
\hline 23 & 2.54 & 0.07 & 0.85 & 0.06 & 17. & 2.3 & 19.0 & 26.9 & 2.0 & 28.9 & 1.15 & 7.9 \\
\hline 24 & 1.62 & 0.07 & 0.54 & 0.06 & 9.0 & 4.8 & 14.0 & 23.6 & 4.5 & 28.1 & 1.07 & 12.0 \\
\hline 25 & 0.90 & 0.06 & 0.64 & 0.05 & 8.1 & 6.6 & 15.0 & 19.2 & 5.6 & 24.8 & 1.18 & 6.0 \\
\hline 26 & 0.14 & 0.04 & 0.20 & 0.06 & 2.6 & 0.0 & 2.6 & 16.8 & 0.6 & 17.4 & - & - \\
\hline 27 & 0.06 & 0.04 & 0.10 & 0.04 & 0.2 & 0.0 & 0.2 & 7.7 & 0.3 & 8.0 & - & - \\
\hline
\end{tabular}



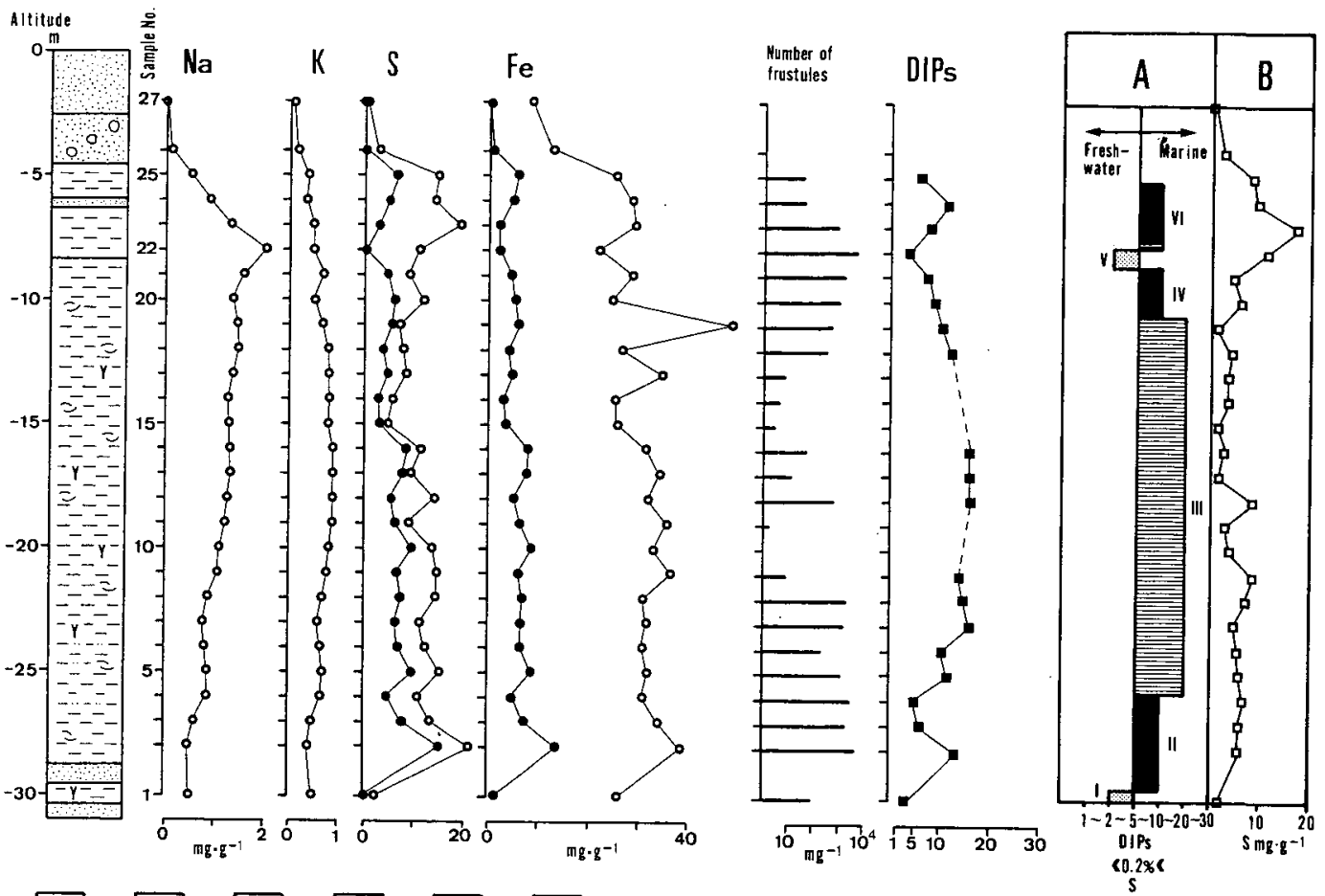

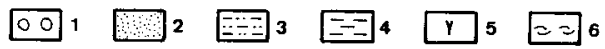

Fig. 3. The vertical profiles of the concentrations $\left(\mathrm{mg} \cdot \mathrm{g}^{-1}\right)$ of sodium, potassium, sulfur and iron $\left(-\mathrm{O}^{-}, 1 \mathrm{~N} \mathrm{HCl}\right.$ and $30 \% \mathrm{H}_{2} \mathrm{O}_{2}$ soluble fractions; - $-30 \% \mathrm{H}_{2} \mathrm{O}_{2}$ soluble fraction), number of diatom frustules and the diatom-based index of paleosalinity (DIPs). (A) Six phases in sedimentary environments distinguished on the basis of the DIPs and pyrite-sulfur content. (B) The vertical variation in acid-soluble sulfur content as an indicator for pyrite oxidation. Sedimentary facies: 1 , gravel; 2 , sand; 3 , fine sand; 4 , silt; 5 , peat; 6 , shell.

Thus, in this paper, sedimentary sulfur dissolved as sulfate into $1 \mathrm{~N} \mathrm{HCl}$ soluble fraction and that into $30 \% \mathrm{H}_{2} \mathrm{O}_{2}$ soluble fraction are ascribed to acid-soluble sulfur and pyrite-sulfur, respectively. The acid-soluble sulfur is thought to be mainly derived from sulfate in sediments (Комa et al., 1983).

Since abundant reactive iron minerals, represented by $1 \mathrm{~N} \mathrm{HCl}$ extractable iron, were found in all the samples, the availability of reactive iron was not a limiting factor for pyrite formation throughout the profile (Table 2, Fig. 3).

Most of the samples contained more than 2.0 $\mathrm{mg} \cdot \mathrm{g}^{-1}$ of acid-soluble sulfur and pyrite-sulfur except for the sample No. 27 from the uppermost part of the profile (Table 2, Fig. 3).
Pyrite-sulfur was not found in the sample No. 1 from the lowermost horizon of $-30 \mathrm{~m}$, the sample No. $22(-8 \mathrm{~m})$ and the samples No. 26 and No. 27 from the uppermost part of the profile, whereas other samples contained more than $2.0 \mathrm{mg} \cdot \mathrm{g}^{-1}$ of pyrite-sulfur (Table 2, Fig. $3)$.

\section{3-3. DIPs}

Enough diatom frustules for a reliable analy. sis could not be obtained in five samples (No. $10,11,15,16$, and 17) from the horizons between $-11 \mathrm{~m}$ and $-25 \mathrm{~m}$, and in two samples (No. 26 and 27) from the uppermost part of the profile. Accordingly, DIPs could not be calculated in these samples. Other samples containing abundant diatom frustules showed DIPs values exceeding 5.0 except for sample No. 1 
$(-30 \mathrm{~m})$ and sample No. $22(-8 \mathrm{~m})$, of which DIPs values were 3.5 and 3.1 , respectively (Table 2, Fig. 3). Relatively high DIPs values in the range of 10.8 to 15.9 were obtained in the samples (No. 5-9, 12-14, 18 and 19) from the horizons between $-11 \mathrm{~m}$ and $-25 \mathrm{~m}$ (Table 2 , Fig. 3).

\section{Discussion}

Koma et al. $(1983,1988)$ studied the relationship between the total sulfur content in muddy sediments and the depositional environment. In these studies, they considered that the amounts less than $0.2 \%$ and more than $0.3 \%$ of total sulfur in muddy sediments might indicate deposition under freshwater and marine environment, respectively. Since pyrite-sulfur comprises more than $80 \%$ of total sulfur in most of the Quaternary sediments (Кома et al., 1983, 1988), the amounts more than $2.0 \mathrm{mg}$ of pyritesulfur per gram sediment sample can be interpreted as an indication of marine deposit.

The low DIPs value of 3.5 and the absence of pyrite-sulfur indicated that sedimentation took place under freshwater conditions in the muddy sediment sample No. 1 from the lowermost part of the profile. At the horizons between $-9 \mathrm{~m}$ and $-28 \mathrm{~m}$ and at the horizons between $-5 \mathrm{~m}$ and $-8 \mathrm{~m}$, the amounts of pyrite-sulfur were more than $2.0 \mathrm{mg} \cdot \mathrm{g}^{-1}$. This corresponds to DIPs values exceeding 5.0. Both pyrite-sulfur content and the DIPs value indicate the marine influence in sedimentary environments at the horizons between $-9 \mathrm{~m}$ and $-28 \mathrm{~m}$ and at the horizons between $-5 \mathrm{~m}$ and $-8 \mathrm{~m}$. Relatively high DIPs values exceeding 10.0 were obtained in the samples containing abundant diatom frustules at the horizons between $-11 \mathrm{~m}$ and $-25 \mathrm{~m}$ (Fig. 3). Although five samples (No. $10,11,15,16$ and 17) from these horizons had too few diatoms to calculate the DIPs, the amounts exceeding $2.0 \mathrm{mg} \cdot \mathrm{g}^{-1}$ of pyrite-sulfur indicate the marine influence in sedimentary environments. Pyrite analysis made up for the lack of diatom data at these horizons. Accordingly, it is considered that the high salinity conditions had continued at the horizons between $-11 \mathrm{~m}$ and $-25 \mathrm{~m}$. It is not uncom- mon for sediments to have few diatoms. Among possible reasons for the paucity of diatom frustules at these horizons, the dissolution of diatom frustules, the small number of diatoms originally living at the time of sedimentation and/or rapid sedimentation rate are most likely.

According to NAKAI et al. (1989), radiocarbon dates at horizons of about $-16 \mathrm{~m}$ and $-17 \mathrm{~m}$ showed a period of 7,000-5,000 yr. B. P., coinciding with the culmination of the Holocene transgression. In their study, higher $\delta^{13} \mathrm{C}$ values exceeding $-25 \%$ and lower $\mathrm{C} / \mathrm{N}$ ratios in the range of 20 to 15 were obtained at these horizons. The results indicate a larger contribution of marine plankton to sedimentary organic matter during the culmination of the Holocene transgression. Therefore, the high salinity conditions at the horizons between $-11 \mathrm{~m}$ and $-25 \mathrm{~m}$ are considered to indicate the Holocene transgression.

At the horizon of $-8 \mathrm{~m}$, pyrite-sulfur was not found and the DIPs showed the lowest value of 3.1 (Fig. 3). This is considered to indicate the predominance of freshwater influence in sedimentary environments. In the uppermost part of the profile, both pyrite-sulfur and diatoms were not found (Fig. 3). It is unlikely that sulfate reduction, which is responsible for pyrite formation, should occur in aerobic conditions such as sandy sediments (Кома et al., 1989). Generally, diatoms are rare in sandy sediments since they may have been washed out of the deposits by water currents. In sandy sediment, it may be difficult to make paleosalinity estimates directly either by diatom or by pyrite analyses.

Although seawater contains abundant sodium and potassium as dissolved ions, no apparent relationship was found between sodium or potassium content in sediments and presumed paleosalinity (Fig. 3). Many variables in addjtion to water composition may influence the retention of ionic species within the sediments, e. g., high rate of ionic diffusion (ENGSTROM and WRIGHT, 1984).

The overall stoichiometry for complete pyrite oxidation is described as follows 
(Postoma, 1983);

$$
\begin{gathered}
\mathrm{FeS}_{2}+15 / 4 \mathrm{O}_{2}+5 / 2 \mathrm{H}_{2} \mathrm{O} \rightarrow \\
\mathrm{FeOOH}+2 \mathrm{SO}_{4}{ }^{2-}+4 \mathrm{H}^{+}
\end{gathered}
$$

Pyrite oxidation is assumed to reflect the increasing sulfate sulfur content in sediments. The sulfur content profile showed that the amounts of acid-soluble sulfur, which include sulfate-sulfur in both sediments and interstitial water, were higher than those of pyrite-sulfur in the samples from the upper horizons between $-5 \mathrm{~m}$ and $-8 \mathrm{~m}$ (Fig. 3). This may indicate that pyrite oxidation occurred at these horizons.

Pyrite-sulfur was not found at the horizon of $-8 \mathrm{~m}$, where the DIPs value of 3.1 showed the predominance of freshwater influence, while abundant acid-soluble sulfur was found (Fig. 3). The predominance of freshwater influence seems to be largely responsible for the absence of pyrite-sulfur at this horizon; the decrease of sulfate supply may have limited the pyrite formation. On the contrary, the presence of acid-soluble sulfur at the horizon of $-8 \mathrm{~m}$ should be understood in connection with the variation in sodium content. The largest amount of sodium at the horizon of $-8 \mathrm{~m}$ may reflect water movements closely related to chemical weathering resposible for pyrite oxidation at the horizons between $-5 \mathrm{~m}$ and $-8 \mathrm{~m}$ (Fig. 3), since sodium usually exists as the form of water-soluble chloride, and chlorides are considered as indicators for water movements (Koma et al., 1983). The increase of sodium content suggests that acid-soluble sulfur may have migrated diagenetically from the upper or lower horizon to the horizon of $-8 \mathrm{~m}$ by water movement. The profiles of acid-soluble sulfur and sodium contents may indicate increased solutional transport of these elements to the horizon of $-8 \mathrm{~m}$ and pyrite oxidation having occurred diagenetically under oxidizing conditions prevailing at the horizons between $-5 \mathrm{~m}$ and $-8 \mathrm{~m}$.

Because of the complementarity between pyrite and diatom analysis in muddy sediments, the present study using diatom analysis combined with selective chemical extraction can provide continuous and more precise information on the changes in sedimentary environments than the individual analyses. Moreover, this method proved to be useful for understanding the diagenetic chemical processes that take place in the sediment after deposition.

\section{Conclusion}

In the present work, a boundary value distinguishing freshwater from brackish/marine depositional condition seemed to be 5.0 in DIPs value and $2.0 \mathrm{mg} \cdot \mathrm{g}^{-1}$ of pyrite-sulfur content in the sediments. Based on the variation in DIPs value, six phases in salinity conditions, each of which is considered to reflect the change in sedimentary environment caused by the marine transgression or regression, were distinguished as summarized in Figure 3A. Among six phases, phase III, including a peroid of 7,000$5,000 \mathrm{yr}$ B. P., showed higher DIPs values exceeding 10.0. This phase is considered to reflect the culmination of the Holocene transgression, which is cosistent with Holocene sealevel changes presumed by variations in $\delta^{13} \mathrm{C}$ values and $\mathrm{C} / \mathrm{N}$ ratios in the same core sample (NAKAI et al., 1989). Variation in acid-soluble sulfur content was useful to estimate the extent of pyrite oxidation that occurred diagenetically under oxidizing conditions (Fig. 3B), which was also indicated by the increase of sodium content in the sediment.

\section{Acknowledgements}

The author wishes to express his sincere thanks to Prof. Y. MAEDA of Yamagata University for his helpful advice and discussions. Heartfelt thanks are expressed to Prof. E. Matsumoto and Prof. N. NakAI of Nagoya University for valuable comments on the manuscript. He also thanks Dr. S. Kumano of Kobe University for his kind encouragement during the course of this study.

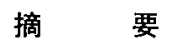

分別化学抽出と珪藻分析を組み合わせた方法に よるコア堆積物（兵庫県豊岡盈地）の古環境解析

分別化学抽出と珠藻分析を組み合わせた方法を 
用いて，兵庫県豊岡盆地の円山川近くで採取され たコア堆積物について堆積環境変化のより詳細な 古環境解釈を得ることを試みた。

堆積物試料を $1 \mathrm{~N} \mathrm{HCl}, 30 \% \mathrm{H}_{2} \mathrm{O}_{2}$ の順で溶解 し, 残りのケイ酸塩画分を珃藻分析に供した。今 回の分析では， $30 \% \mathrm{H}_{2} \mathrm{O}_{2}$ 溶解画分に溶出した黄鉄 鉱イオウ $\left(\mathrm{FeS}_{2}-\mathrm{S}\right)$ の含有量から海成堆積物と淡 水成堆積物を区別し,さらに, 堆積環境の塩分濃 度変化を数量的に評価するために新しく珪藻古塩 分濃度指数 (DIPS) を算出した。湝質堆積物にお いて黄鉄鉱イオウ分析と珪藻分析が相互に補足し 合うことにより，本法は古環境変遷について連続 かつ詳細な情報を提供した。

黄鉄鉱イオン含有量と珪藻古塩分濃度指数傎の 変動に基づいて, 本コアの堆積物から塩分濃度変 化を反映する 6 つの堆積相が識別され，それぞれ は海進あるいは海退を反映するものと考えられた。 その堆積相の変遷は同一コアにおいて, 中井活か （1989）によって明らかにされた有機物炭素の $\delta^{13} \mathrm{C}$ および $\mathrm{C} / \mathrm{N}$ 比からみた完新世の海面変動と矛盾し ない。

\section{References}

American Public Health Association, American Water Works Association, and AMErican Pollution Control Federation (APHa AWWA WPCF) (1985): Standard methods for the examination of water and wastewater, 16th ed. American Public Health Association.

BERNER, R. A. (1984): Sedimentary pyrite formation: an update. Geochim. Cosmochim. Acta, 48: 605-615.

BERNER, R. A. and R. RAISwELl (1984): C/S method for distinguishing freshwater from marine sedimentary rocks. Geology, 12: 365-368.

ChIGIRA, M. (1988): Chemical weathering of mudstone of the Pleistocene Haizume Formation, Niigata Prefecture, central Japan. Jour. Geol. Soc. Japan, 94: 419-431. (in Japanese with English summary).

Cleve-Euler, A. (1951-1955): Die Diatomeen von Schweden und Finnland I-V, p. 1-155, 1-143, 1149, 1-240, 1-217. In Kungliga Svenska Vetenskapsakademiens Handlingar, 2(1), 3(3), 4(1), 4(5), 5(4). J. Cramer.

DENYS, L. (1985): Diatom analysis of an AtlanticSubboreal core from Slijpe (western Belgian coastal plain). Review of Paleobotany and Palynology, 46: 33-53.

ENGSTROM, D. R. and H. E. WRIGHT, Jr (1984): Chemical stratigraphy of lake sediment as a record of environmental change, p. 11-67. In E Y. HaworTh and J. W. G. Lund (eds.), Lake sediments and Environmental History. Leicester University Press.

Hustedt, F. (1930-1966): Die Kieselalgen, p. 1-920, 1-845, 1-816. In L. Rabenhorst (ed.), Kryptogamen-Flora von Deutschland, Österreich und der Schweiz, $7(1,2,3)$.

JoHn, J. (1983): The diatom flora of the Swan River Estuary, Western Australia. Bibliotheca Phycologica, Band 64. J. Cramer, Vaduz.

Kitano, Y., M. Sakata and E. Matsumoto (1980): Partitioning of heavy metals into mineral and organic fractions in a sediment core from Tokyo Bay. Geochim. Cosmochim. Acta, 44: 1279-1285.

Koma, T., Y. Suzuki and K. Kodama (1983): Forms of sulfur, carbon, chlorine and iron compounds and their depositional environment, in the Kazusa Group, the Boso Peninsula, central Japan. Bull. Geol. Surv. Japan, 34: 191-206. (in Japanese with English summary).

Koma, T., K. Ando, A. Unozawa and T. Sakamoto (1988): Geochemical study on sedimentary environment of Quaternary mudstones of $\mathrm{Ur}$ izura Hill, Ibaraki Prefecture, Japan. Bull. Geol. Surv. Japan, 39: 573-599. (in Japanese with English summary).

Koma, T., Y. Suzuki and S. Togashi (1989): Geochemical and mineralogical study of Plio-Pleistocene mudstone taken from some holes drilled in the southeast part of Kanto Plain, central Japan. Jour. Japan. Assoc. Petrol. Techn., 54: 1-17. (in Japanese with English summary).

Lowe, R. L. (1974): Environmental requirements and pollution tolerance of freshwater diatoms. National Technical Information Service, U. S. Department of Commerce.

Nakai, N., T. Ohta, H. Fujisawa and M. Yoshida (1982): Paleoclimatic and sea-level changes deduced from organic carbon isotope ratios, $\mathrm{C} /$ $\mathrm{N}$ ratios and pyrite contents of cored sediments from Nagoya Harbor, Japan. The Quatern. Res. (Daiyonki-Kenkyu), 21: 169-177. (in Japanese with English summary).

Nakal, N., T. Ohta, S. Ohishi, N. Baba, S. Kusunoki, S. Yoshioka and Y. MaEda (1989): Sea-level changes during the Holocene based on the vertical profile of organic ${ }^{13} \mathrm{C}$ and $\mathrm{C} / \mathrm{N}$ and AMS ${ }^{14} \mathrm{C}$-ages (II). Proceedings of the Annual Meeting of the Japan Association for Quaternary Research, August 18-21, 1989, Tottori, Japan. p. 126-127. (in Japanese). 
Patrick, R. and C. W. Reimer (1966): The Diatoms of the United States, 1. Acad. Nat. Sci.

Patrick, R. and C. W. Reimer (1975): The Diatoms of the United States, 2(1). Acad. Nat. Sci.

Postoma, D. (1982): Pyrite and siderite formation in brackish and freshwater swamp sediments. Am. Jour. Sci., 282: 1151-1183.

Postoma, D. (1983): Pyrite and siderite oxidation in swamp sediments. Jour. Soil Sci., 34: 163-182.

Sato, H. and S. Kumano (1985): The succession of diatom assemblages and Holocene sea-level changes during the last 6,000 years at Sado Island, central Japan: The Holocene development of Lake Kamo-ko I . Jpn. J. Limnol., 46: 100-106.

Sato, H and S. Kumano (1986): The succession of diatom assemblages and Holocene sea-level changes during the last 6,000 years at Sado Island, central Japan: The Holocene development of Lake Kamo-ko II. Jpn. J. Limnol., 47: 175-181.
SATo, H. (1989): Sulfur analysis of the sediment by the $\mathrm{H}_{2} \mathrm{O}_{2}$ treatment-turbidimetric method: a simple method for studying the paleoenviron. ment. The Quatern. Res. (Daiyonki-Kenkyu), 28: $35-40$. (in Japanese with English summary).

VAN DER WERFF, F. and H. HuLs (1957-1974): Diatomeenflora van Nederland. Abcoude. 10 fasc. in 1 volume. Reprinted at Koenigstein 1976.

(著者: 佐藤裕司, 兵庫県教育委員会事務局社会教 育 - 文化財課自然系博物館（仮称）設立準備室, $\overline{\mathbf{T}}$ 650 神戸市中央区中山手通 6-1-1; Hiroshi SAT0, Natural History Muzeum and Institute Projects, Administration Office, Hyogo Prefectural Board of Education, Chuo-ku, Kobe, 650)

Received: 20 April 1990

Accepted: 12 March 1991 